\title{
Fiscal Policy and Monetary Policy: Sensitivity Analysis
}

\author{
Muhamad Yunanto and Henny Medyawati
}

\begin{abstract}
Economic policy focuses on the management of macroeconomic stability, fiscal policy will interact with monetary policy to control macroeconomic balance. The purpose of this study is to analyze the fiscal and monetary policy to gross domestic product. The sensitivity analysis was performed to explain the change of policy shocks on macroeconomic indicators. The analysis method in this research is using error correction model of Engle Granger (ECM-EG), which estimates the short-term and Two Stages Least Square for the long term estimates.
\end{abstract}

Index Terms-Fiscal policy, monetary policy, sensitivity analysis, macroeconomic indicators.

\section{INTRODUCTION}

Development of some macroeconomics indicators fluctuate basically inseparable from the development of macroeconomic policies and structural policies in the financial markets carried out by the Indonesian government and the central bank in almost three decades. Developments in the financial sector can be quite rapid if not offset by developments in the real sector, in turn, led to structural imbalances in the economy [1]. On the under-capacity economy, the fiscal and monetary expansionary policies effectively affect to real output. Reference [2] describes the optimal monetary policy response will be influenced by several shock scenarios on the impact of fiscal policy and monetary and fiscal policy interactions on social welfare will be positive if the fiscal policy is exogenous. Expansionary fiscal policy, through fiscal stimulus to increase aggregate demand through domestic consumption and investment, assuming constant prices, short term real output will increase [3]. The study uses financial Computable General Equilibrium. The results show that under conditions of financial crisis or economic downturn, the combination of fiscal expansion policy and monetary expansion is very effective to boost economic growth. Developments in the real sector, in turn, led to structural imbalances in the economy [1]. Economic policy focuses on the management of macro-economic stability, fiscal policy will interact with monetary policy to control the macroeconomic balance. Fiscal policy aims to influence aggregate demand side of the economy short term. In addition, this policy can also affect the supply side in the long run through increased economic capacity. Monetary policy is generally analyzed two interrelated main scope, namely: first, the selection variable modeling and monetary policy. Secondly, related to the monetary policy in the economy which expanded research

Manuscript received January 15, 2015; revised April 8, 2015. This paper is a part of M. Yunanto's dissertation.

The authors are with the Faculty of Economics, Gunadarma University, Indonesia (e-mail: myunanto@staff.gunadarma.ac.id, henmedya@staff.gunadarma.ac.id). data range to 2014 .

This study is a continuation of previous studies that have been done by [4]-[7]. The sensitivity analysis on the model of research conducted in this study to obtain information about the effect of shocks on the behavior of the variables in the model, in particular with regard to how long the effects of shock occurs, how much influence the shock and how long it takes to get back on its long-term equilibrium. In a previous study, as in [6] have obtained the equation in the form of reduced form and has analyzed the macro policy to obtain internal and external balance. Contribute ideas for the implementation of macro-economic policy short and long term, fiscal and monetary policies, especially in the form of rationale in order to implement the strategy of economic policy, fiscal and monetary arrangements in Indonesia theoretical framework.

\section{A. The Monetary and Fiscal Policy}

Macroeconomic policy is the monetary and fiscal policy. Monetary policy covers all government actions aimed at influencing the course of the economy through the addition or reduction of the amount of money in circulation (money supply), it is said that the instrument is a variable $\mathrm{M}$, which is the amount of money in circulation is called also offer money supply. Fiscal policy is all the actions taken by the government, aiming to influence the course of the economy through the addition or government subtraction and or tax expenditures, have tax or $T_{x}$, or the payment or transfer of $T_{r}$, and government spending, or $\mathrm{G}$ [8].

\section{B. Mundell-Fleming Model}

Mundell-Fleming theory or a two-country model is an analytical framework that can be used to explain the international transmission due to the influence of the global economy on a small open economy [9]. This theory explains that the expansion of monetary policy will result in an increase in a country's output and produce a negative output response to other countries. Transmission mechanism of the model can be viewed via trade, where a country will lower the interest rate, so the exchange rate depreciates and create competitive rivalry. With such a country will have a surplus in the trade balance as a result of increasing the products are exported, the case will reduce imports from other countries. Mundell-Fleming model is not much different from the IS-LM model. Both of these models emphasize the interaction between the goods market and the money market. They also assume that the price level is fixed and indicates what causes short-term fluctuations in aggregate income (or, together with a shift in the aggregate demand curve). The difference is that the IS-LM model assumes a closed economy, while the Mundell-Fleming model assumes an open economy [4]. The Mundell-Fleming makes an important and extreme assumption, namely this model assumes that the economy being studied is a small open 
economy with perfect capital mobility. That is, the economy can borrow or lend as much as desired in the world financial markets.

\section{Related Research}

Characteristics of small open economies such as Indonesia is, (1) the economy with a very high level of dependence on the global economy; (2) a relatively stable economy, with high levels of vulnerability to shocks from abroad; and (3) the high degree of dependence on the international price changes [10]. Mundell-Fleming theory or a two-country model is an analytical framework that can be used to explain the international transmission due to the influence of the global economy on a small open economy [9]. This theory explains that the expansion of monetary policy will result in an increase in a country's output and produce a negative output response to other countries. Transmission mechanism of the model can be viewed via trade, where a country will lower the interest rate, so the exchange rate depreciates and create competitive rivalry. With such a country will have a surplus in the trade balance as a result of increasing the products are exported, the case will reduce imports from other countries. In a small open economy with relatively unstable characteristics, the level of vulnerability to foreign shocks and the degree of dependence on high international price changes, causing the need for macroeconomic policies to maintain stability. Monetary policy as one of the macro-economic policy is generally applied in line with the business cycle [11]. Fiscal stimulus can immediately increase economic activity, while monetary policy will take longer to show the impact on the economy. This is because the primary goal of monetary policy is to maintain a stable output gap and inflation. In developed countries, like the United States and major European countries, there is substantial evidence of the effectiveness of monetary policy innovations on real economic parameters, [12], [13], [14], and [15].

Reference [16] analyzed four models for the exchange rate IDR/USD. The four models are models of purchasing power parity, the uncovered interest parity models, monetary models and models of the Mundell-Fleming expanded. According to the empirical results, the model of purchasing power parity, the sign of the coefficients have the expected positive sign and is significant at the $1 \%$ level. The results of data processing show that the models which is can be used for the Indonesian case is a model of Bilson and Frenkel models.

\section{Methodology}

\section{A. Data}

The data in this study are quarterly data from 1990:1 to 2014:3 in the form of time series data. Quarterly data based on constant values with base year in 2005, except for the data in the form of index values and percentages. The data comes from Financial Statistics (IFS) published by Bank Indonesia, Central Bureau of Statistics (BPS). Other data sourced from the Organization for Economic Co-operation and Development (OECD). The model in this study is adopted from previous research models composed of 11 short-term structural equations, structural equation derived based on the assumption that the economy is represented by homogeneous economic actors [5]. Data is tested through unit root test and cointegration test, while the methods for estimating equations using the Error Correction Model (ECM-Granger) in short term and 2SLS for long term estimates. The operational description of variables explained below.

1) Gross Domestic Product (GDP) is the value of the total national output in scale units trillion dollars are calculated based on constant price or calculated value of real output in the base year 2005

2) Private Consumption Expenditure (KONS) is the amount of household consumption in scale units trillion

3) Investment Expenditures (INV) is a private investment spending in scale units trillion

4) Government Consumption (KONP) is realized in government spending in the National Budget in the scale unit trillion.

5) Export (EKSP) is the value of exports of goods and services in scale units trillion.

6) Import (IMPR) is the value of imports of goods and services in scale units trillion

7) Consumer Price Index (IHK) is an indicator that is used as a measure in determining the amount of the unit digit inflation indices, namely volatility rising prices quickly and sustainably

8) World Crude Oil Prices (HMMD) expressed in the scale of the USA Dollars per barrel. Variable oil is used to represent the world inflation

9) Interest Rate (BIRATE) is the interest rate policies that reflect the attitude or stance of monetary policy set by the Bank Indonesia and announced to the public

10) Supply of money (M2) or MS is the value of the amount of money circulating in the broad sense (M2) in the scale unit trillion

11) Foreign Assets Net (KBLN) is worth abroad in scale units trillion at the end of the period

12) Employment (LK) is the number of population (million people) are working based on labor force participation rate of the labor force every 6 months

13) Exchange rate (KURS) or Exchange Rates IDR / USD is the value of one unit of domestic currency if the amount of currency exchanged for other countries

14) World Export Price Index (HREKS) is the world export price index change in percent which is a combination of all the consumer price index of all countries in the world by performing weighting based on the criteria of the IMF.

The model in this study is adopted from previous research models by [5], as shown below.

- Block of Goods Market

Private consumption equation

$$
\begin{gathered}
\text { KONS }=f\left(Y_{D}, \text { BIRATE }\right) \\
C_{t}=\alpha_{0}+\alpha_{1}(Y-T x+T r)_{t}+\alpha_{2} i_{t}+\varepsilon_{1 t} \\
\alpha_{2}<0 ; \alpha_{1}>0
\end{gathered}
$$

Investment Equation

$$
\begin{gathered}
I N V=f(K B L N, B I R A T E) \\
I_{t}=\beta_{0}+\beta_{1} F_{t}+\beta_{2} i_{t}+\varepsilon_{2 t} \\
\beta_{2}<0 ; \beta_{1}>0
\end{gathered}
$$

Government Expenditure Equation

$$
K O N P_{t}=f(P P J K, P D B E)
$$




$$
\begin{gathered}
G_{t}^{*}=\gamma_{0}+\gamma_{1} T x_{t}+\gamma_{2} Y_{t}+\varepsilon_{3 t} \\
\gamma_{0}, \gamma_{1}>0
\end{gathered}
$$

Export Equation

$$
\begin{gathered}
E K S P=f((H R E K S), I M P D N) \\
X_{t}=\delta_{0}+\delta_{1}\left(r . P_{x}^{*} / P\right)_{t}+\delta_{2} M_{-} W_{t}+\varepsilon_{4 t} \\
\delta_{1}, \delta_{2}>0
\end{gathered}
$$

Import Equation

$$
\begin{gathered}
I M P R=f(H R I M P), E K S P, Y D O M) \\
M_{t}=\zeta_{0}+\zeta_{1}\left(r . P_{m}^{*} / P\right)_{t}+\zeta_{2} X+\zeta_{3}(C+I+G)_{t}+\varepsilon_{5 t} \\
\zeta_{1}<0 ; \zeta_{2}, \zeta_{3}>0
\end{gathered}
$$

Money Supply Equation

$$
\begin{gathered}
M_{D}=M_{S} \\
M_{S} / I H K=M / I H K \\
M_{D}=M / I H K \\
M 2_{t}=f(M 1, P D B E, B I R A T E) \\
M 2_{t}=\eta_{0}+\eta_{1} M 1+\eta_{2} Y_{t}+\eta_{3} i_{t}+\varepsilon_{6 \mathrm{t}} \\
\eta_{3}<0 ; \eta_{1}, \eta_{2}>0
\end{gathered}
$$

- Block of the Balance of Payment

Exchange Rate Equation

$$
\begin{gathered}
\text { KURS }=f(\text { IREL, BIRATE, KBLN }) \\
r_{t}=\theta_{0}+\theta_{1}\left(P^{*} / P\right)_{t}+\theta_{2} i_{t}+\theta_{3} F_{t}+\varepsilon_{7 t} \\
\theta_{2}, \theta_{3}<0 ; \theta_{1}>0
\end{gathered}
$$

Price (inflation) and Purchasing Power Parity Equation

$$
\begin{gathered}
I H K=f((P P P), M 2, H M M D) \\
P_{t}=\kappa_{0}+\kappa_{1}\left(r . P^{*}\right)_{t}+\kappa_{2} M 2_{t}+\kappa_{3} O i l_{-} W_{t}+\varepsilon_{8 t} \\
\kappa_{1} \kappa_{2} \kappa_{3}>0
\end{gathered}
$$

Net Foreign Account Equation

$$
\begin{gathered}
K B L N=f(R I N T R, K U R S) \\
F_{t}=\lambda_{0}+\lambda_{1}\left(i-i^{*}\right)_{t}+\lambda_{2} r_{t} \varepsilon_{9 t} \\
\lambda_{1}<0 \lambda_{2}>0
\end{gathered}
$$

\begin{tabular}{|c|c|c|c|}
\hline \multirow[t]{2}{*}{ Sim } & \multicolumn{2}{|l|}{ Changing variables } & \multirow{2}{*}{ Information } \\
\hline & Variables & Value & \\
\hline \multirow[t]{3}{*}{1} & Interest rates & $\downarrow 10 \%$ & Monetary Expansion \\
\hline & Tax revenue & $\downarrow 10 \%$ & Fiscal expansion \\
\hline & Foreign Capital inflows & $\uparrow 20 \%$ & \\
\hline \multirow[t]{3}{*}{2} & Interest rates & $\uparrow 10 \%$ & Monetary contraction \\
\hline & Tax revenue & $\uparrow 10 \%$ & Fiscal contraction \\
\hline & Foreign Capital inflows & $\downarrow 20 \%$ & \\
\hline \multirow[t]{4}{*}{3} & Interest rates & $\downarrow 10 \%$ & Monetary Expansion \\
\hline & Tax revenue & $\uparrow 10 \%$ & Fiscal Contraction \\
\hline & Variables & Value & \\
\hline & Foreign Capital inflows & $\uparrow 20 \%$ & \\
\hline \multirow[t]{3}{*}{4} & Interest rates & $\uparrow 10 \%$ & Monetary contraction \\
\hline & Tax revenue & $\downarrow 10 \%$ & Fiscal expansion \\
\hline & Foreign Capital inflows & $\downarrow 10 \%$ & \\
\hline \multirow[t]{3}{*}{5} & Interest rates & $\downarrow 50 \%$ & Monetary Expansion \\
\hline & Tax revenue & $\downarrow 50 \%$ & Fiscal expansion \\
\hline & Foreign Capital inflows & $\uparrow 50 \%$ & \\
\hline \multirow[t]{3}{*}{6} & Interest rates & 个50\% & Monetary contraction \\
\hline & Tax revenue & $\uparrow 50 \%$ & Fiscal contraction \\
\hline & Foreign Capital inflows & $\downarrow 50 \%$ & \\
\hline \multirow[t]{3}{*}{7} & Interest rates & $\downarrow 50 \%$ & Monetary Expansion \\
\hline & Tax revenue & $\uparrow 50 \%$ & Fiscal contraction \\
\hline & Foreign Capital inflows & $\uparrow 50 \%$ & \\
\hline \multirow[t]{3}{*}{8} & Interest rates & $\uparrow 50 \%$ & Monetary contraction \\
\hline & Tax revenue & $\downarrow 50 \%$ & Fiscal expansion \\
\hline & Foreign Capital inflows & $\downarrow 50 \%$ & \\
\hline
\end{tabular}

- Block of Aggregate Supply

National Production Equation

$$
\begin{gathered}
P D B E=f(I N V, L K) \\
Y_{t}=\mu_{0}+\mu_{1} I_{t}+\mu_{2} L_{t}+\varepsilon_{10 t} \\
\mu_{1}, \mu_{2}, \mu_{3}>0
\end{gathered}
$$

Employment Equation

$$
\begin{gathered}
L K=f(P D B E, I H K) \\
L_{t}=v_{0}+v_{1} Y_{t}+v_{2} P_{t}+\varepsilon_{11 t} \\
v_{1}, v_{2}>0
\end{gathered}
$$

\section{B. Shock Scenario Simulation, Sensitivity Analysis and Policy Scenarios}

To see the sensitivity of the model to a shock (changes) then the sensitivity test is done by applying a shock into the model. This test is useful to see the reaction of the variables in the model (from a positive or negative sign) due to shock one variable exogenous. In addition, the results of these tests can also provide information on how the shock effect of the behavior of the variables in the model, in particular with regard to how long the influence of shock occurs, how big the influence of shock and how long it takes to get back on a long-term balance. The following eight policy scenario performed in this study.
TABLE I: POLICY SIMULATION SCENARIO

\section{RESULT AND DISCUSSION}

\section{A. Unit Root Test and Cointegration Test}

The stationery test of data has been performed on 23 observation data with the test equation includes a constant (intercept) at the 5\% critical value. Stationery test of data is done using the ADF (Augmented Dickey Fuller) Unit Root Test. The results of the unit root test shows that there are three variables that have been stationary at the level of the level, the variable BIRATE (Bank of Indonesia interest rate), PDBE (Gross Domestic Product) and YD (Disposable Income). These results same as previous research conducted by [6]. The cointegration test results indicate that all variables in the entire equation in this study have cointegration among those variables. It can be concluded that there is a long-term equilibrium relationship between the variables.

\section{B. Estimation Model of Short-Term and Long-Term}

The results of residual normality test committed against structural equations, obtained the error term normally distributed. Based on the value of the probability distribution of the error term with a $95 \%$ confidence level, the results show that each equation unless exchange rates and prices, residual is normally distributed. Autocorrelation test results indicate the occurrence of autocorrelation on exchange rate equation, is an indication of the implementation of the operations of the market and the stability of exchange rates of foreign currency against domestic conducted by the Monetary Authority. On the other hand, the problem of heteroscedasticity is resolved by giving a check mark on a menu heteroscedasticity consistent covariance and white. The results of testing performed on the entire parameters equation being estimated, no multicollinearity symptoms.

Dynamic simultaneous equations in this study are over-identified as shown in Table II. Over-identified equations solved by TSLS, that is a common method used to 
estimate the simultaneous equations [17]

TABEL II: IDENTIFICATION OF SIMULTANEOUS EQUATIONS

\begin{tabular}{llccccc}
\hline \hline No. & Equation & $K$ & $k$ & $m$ & $\left(K^{-\mathrm{k}}\right)$ & $\left(m^{-1}\right)$ \\
\hline 1. & KONS( C) & 10 & 1 & 2 & 9 & 1 \\
2. & INV(I) & 10 & 1 & 2 & 9 & 1 \\
3. & KONP(G) & 10 & 2 & 1 & 8 & 0 \\
4. & EKSP(X) & 10 & 1 & 2 & 9 & 1 \\
5. & IMPR(M) & 10 & 0 & 4 & 10 & 3 \\
6. & M2 & 10 & 2 & 2 & 8 & 1 \\
7. & KURS(r) & 10 & 1 & 3 & 9 & 2 \\
8. & IHK(P) & 10 & 1 & 3 & 9 & 2 \\
9. & KBLN(F) & 10 & 1 & 2 & 9 & 1 \\
10. & PDBE(Y) & 10 & 0 & 3 & 10 & 2 \\
11. & LK(L) & 10 & 0 & 3 & 10 & 2 \\
\hline \hline
\end{tabular}

TABLE III: SUMMARY OF SHORT TERM AND LONG TERM COEFFICIENT

\begin{tabular}{|c|c|c|c|c|}
\hline No. & $\begin{array}{l}\text { Dependen } \\
\text { Variables }\end{array}$ & $\begin{array}{l}\text { Independen } \\
\text { Variables }\end{array}$ & ST & LT \\
\hline \multirow[t]{4}{*}{1.} & Log(kons) & Konstanta & $0.015^{* *}$ & $4.742 * * *$ \\
\hline & & $\log (Y D)$ & 0.00033 & $0.002 * * *$ \\
\hline & & LOG(BIRATE) & -0.00047 & 0.002 \\
\hline & & ECT & $-0.084 * *$ & \\
\hline \multirow[t]{4}{*}{2.} & $\log (\mathrm{INV})$ & Konstanta & 0.023 & $1.706^{* * * *}$ \\
\hline & & Log(BIRATE) & -0.002 & $-0.0818 * * *$ \\
\hline & & $\log (\mathrm{KBLN})$ & 0.002 & $0.624 * * *$ \\
\hline & & ECT & 0.057 & \\
\hline \multirow[t]{4}{*}{3.} & $\log (\mathrm{KONP})$ & Konstanta & 0.015 & $-2.178 * * *$ \\
\hline & & $\log (\mathrm{PPJK})$ & 0.007 & $0.178^{* *}$ \\
\hline & & $\log (\mathrm{PDBE})$ & -0.379 & $0.835^{* * * *}$ \\
\hline & & ECT & $-0.720 * * *$ & \\
\hline \multirow[t]{4}{*}{4.} & $\log (\mathrm{EKSP})$ & Konstanta & 0.013 & $-0.987 * * *$ \\
\hline & & $\log ($ HREKS $)$ & $0.673 * * *$ & $1.422 * * *$ \\
\hline & & $\log (\mathrm{IMPDN})$ & $0.225 * *$ & $0.560 * * *$ \\
\hline & & $\mathrm{ECT}$ & -0.123 & \\
\hline \multirow[t]{5}{*}{5.} & $\log (\mathrm{IMPR})$ & Konstanta & 0.003 & $1.326^{* * *}$ \\
\hline & & Log(HRIMP) & 0.042 & 0.104 \\
\hline & & $\log (\mathrm{YDOM})$ & 0.0002 & $0.0006 * *$ \\
\hline & & LOG(EKSP) & $0.693 * * *$ & $0.604 * * *$ \\
\hline & & ECT & $-0.345^{* * *}$ & \\
\hline \multirow[t]{5}{*}{6.} & $\log (\mathrm{M} 2)$ & Konstanta & $0.009 * *$ & $1.065 * * *$ \\
\hline & & $\log (\mathrm{M} 1)$ & $0.462 * * *$ & $2.077 * * *$ \\
\hline & & $\log (\mathrm{PDBE})$ & $0.150^{*}$ & $-0.861 * *$ \\
\hline & & $\log ($ BIRATE) & -0.0006 & $0.005^{* *}$ \\
\hline & & ECT & $-0.097 * *$ & \\
\hline \multirow[t]{5}{*}{7} & $\log ($ KURS $)$ & Konstanta & 0.010 & $-0.459 * * *$ \\
\hline & & $\log ($ IREL $)$ & $0.621 * * *$ & $0.683 * * *$ \\
\hline & & $\log ($ BIRATE) & $0.011 * * *$ & $0.008 * * *$ \\
\hline & & $\log (\mathrm{KBLN})$ & $-0.092 * * *$ & $0.446^{* * * *}$ \\
\hline & & ECT & $-0.394 * * *$ & \\
\hline \multirow[t]{5}{*}{8.} & $\log (\mathrm{IHK})$ & Konstanta & $0.031 * * *$ & $-4.524 * * *$ \\
\hline & & $\log (\mathrm{PPP})$ & $0.137 * * *$ & $0.406^{* * *} *$ \\
\hline & & $\log (\mathrm{M} 2)$ & $-0.372 * * *$ & $0.780 * * *$ \\
\hline & & $\log (\mathrm{HMMD})$ & $-0.033 * *$ & $0.195 * * *$ \\
\hline & & ECT & $-0.073^{* * *}$ & \\
\hline \multirow[t]{4}{*}{9.} & $\log (\mathrm{KBLN})$ & Konstanta & $0.027 * *$ & $4.382 * * *$ \\
\hline & & Log(RINTR) & $0.010 * * *$ & 0.0003 \\
\hline & & $\log ($ KURS $)$ & -0.105 & $0.695^{* * *}$ \\
\hline & & ECT & -0.070 & \\
\hline \multirow[t]{4}{*}{10.} & $\log (\mathrm{PDBE})$ & Konstanta & $0.012 * *$ & $-7.864 * * *$ \\
\hline & & $\log (\mathrm{INV})$ & $0.106^{* * *} *$ & $0.245^{* * *}$ \\
\hline & & $\log (\mathrm{LK})$ & 0.725 & $2.892^{* * * *}$ \\
\hline & & ECT & $-0.184 * *$ & \\
\hline \multirow[t]{4}{*}{11.} & $\log (\mathrm{LK})$ & Konstanta & $0.004 * * *$ & $3.117 * * *$ \\
\hline & & $\log (\mathrm{PDBE})$ & 0.017 & $0.197 * * *$ \\
\hline & & $\log (\mathrm{IHK})$ & -0.014 & $0.037 * * *$ \\
\hline & & $\mathrm{ECT}$ & -0.070 & \\
\hline
\end{tabular}

Note: $* * *$ significant of $1 \%$, **significant $5 \%$, significant $10 \%$

In line with the basic theory Keyness, in the short and long term consumption model estimation results show the positive effect of disposable income on consumption. The estimation results indicate that autonomous consumption has a positive and significant value in accordance with the theory. Elasticity of consumption to interest rates, theoretically prove that the increase in deposit rates will increase the cost of the use of the current period to encourage consumers to reduce consumption and divert it to the next period.

\section{Sensitivity of GDP against Incoming Foreign Capital Flows}

Sensitivity testing is done by using structural equation results that have been tested. Variables given shock is an instrument of economic policy, namely fiscal policy to give a shock in tax revenue (fiscal stimulus) and monetary policy through changes in interest rates. Capital flow variable is measured by Net Foreign Assets, used in a variety of situations and inflows of foreign capital outflows. The magnitude of shocks given in light scale policy changes by ten percent $(10 \%)$ and fifty percent $(50 \%)$ for both the combination policy is contraction or expansion. The magnitude of the shock is given to test simulation economic policies pessimistic and optimistic, in addition to forecasting the basic model (baseline). Testing was conducted on models in 2000 quarter one to four. This simulation is carried out for a range $1997 \mathrm{q} 3$ to $2010 \mathrm{q} 4$ which represents a flexible exchange rate system, a decision that took effect since August 14, 1997.

Capital outflow is calculated by calculating the reduction in net foreign wealth in every period of the simulation. Capital outflow affects the economy as it did in the GDP contraction. Transmission capital flows out of the macro-economic conditions is traced based on the model used is strongly associated with the investment and the exchange rate. increased capital outflows of investment has resulted in the decline of foreign elements subsequently resulted in the weakening of the rupiah against the US dollar. With the weakening of the rupiah is the macroeconomic variables will quickly changes. The liquidity of the economy decreased so that the aggregate demand has decreased, along with the aggregate supply experienced a contraction. The more expensive production cost of raw materials with a high import content due to the weakening of the rupiah exchange rate has reduced the incentive to do the production.

A crisis situation that ever hit the trigger foreign investor confidence is followed by the flow of capital out of the performance of the national economy will be declining rapidly in a wide range of implications. The test results reinforced the indication of the structure of the national economy is indeed vulnerable to capital flows out.

\section{Gross Domestic Product Sensitivity of Economic} Policy at the Time of Incoming Foreign Capital Outflows

Economic policies that deliver shock to the period of study include expansionary fiscal policy, contraction of fiscal policy, expansionary monetary policy and contraction of monetary policy. In the simulation of up to eight, economic policy shocks take place simultaneously. Furthermore, the model sensitivity test is done with two scenarios on the interest rate of $10 \%$ (monetary expansion), the increase rate of $10 \%$ (monetary contraction), raising the tax rate of $10 \%$ (fiscal contraction) and a lower tax rate of $10 \%$ (fiscal 
expansion). Shock period began in the first quarter to the fourth quarter of 2000. The use of economic variables is basically an application of macroeconomic policy responses that can be taken by the government in accordance with existing policy choice.

TABEL IV: The RESUlt OF POLICY CHANGES TO THE BASELINE SIMULATION MODELS

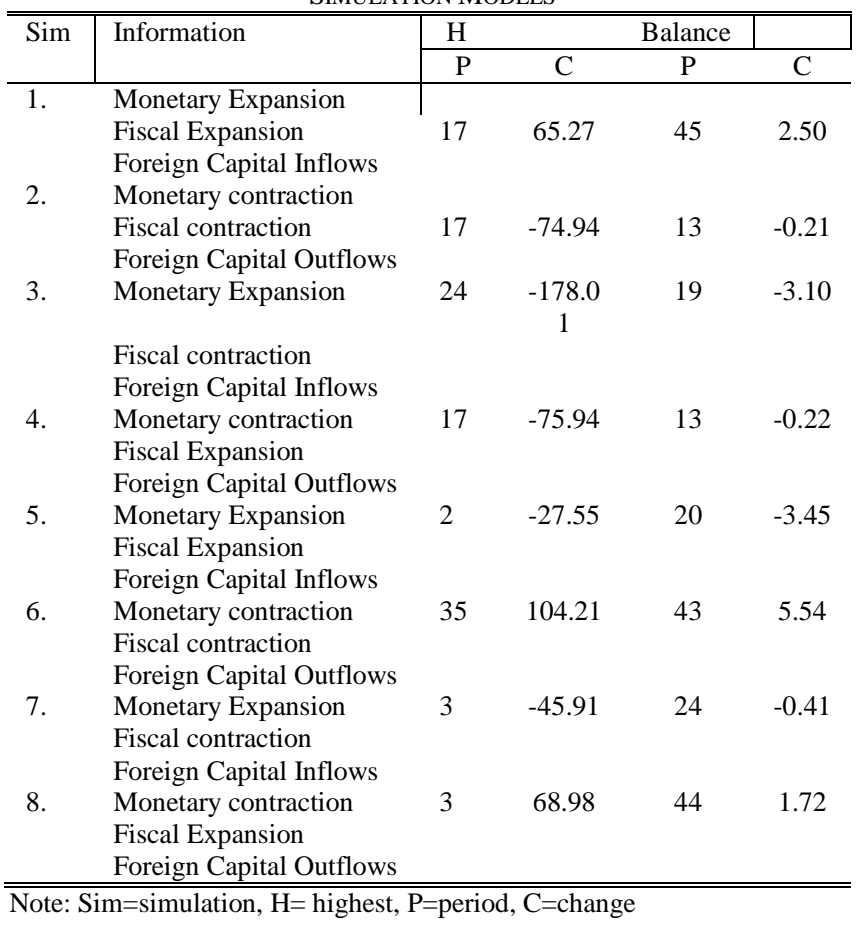

Based on sensitivity testing, in general the response of macroeconomic variables to the application of a monetary policy expansion does not provide a change of the basic model but monetary contraction showed the opposite relationship to GDP. In the early period of several variables such as private consumption, investment, exports, imports and the money supply show the opposite direction, the next also move in the direction that follows the movement of the investment. This indicates a pause or lag of the impact of monetary policy on the economy. The results generated by monetary expansion shows the effect in the short term, the long term effect is permanent in inflation.

From the simulation results can be analyzed that, GDP is likely to increase if the government implements economic policies as in normal conditions, i.e. with the expansionary of fiscal policy and monetary policy contraction. In terms of GDP, the combination of fiscal and monetary policies provide significant ripple effect to stimulate aggregate demand through increased consumption, investment, government spending and net exports. In addition, aggregate demand is strong enough also to encourage the business sector to increase production in order to meet the demand. As a result of policy synergies, potential rise in interest rates due to expansionary fiscal policy is offset by monetary policy easing inflationary pressures.

\section{CONCLUSION}

There are several reasons why monetary and fiscal policies should be coordinated within the framework of price stability and growth. First, there are limitations of the instruments to reach the targets. These limitations can be derived from a consideration of the impact on the target instrument which can be distinguished for the short-term and long-term. Second, maintain the stability of output and the inflation to deteriorate, as a result of lack of coordination between monetary and fiscal policy. Coordination of monetary and fiscal policy can provide a clear separation of the two policies on the basis of the structure of the grace period policy. Third, the importance of coordination between monetary and fiscal policy is the difference in perception between the two authorities, what is best for the nation.

The estimation of the equation in this study are consistent with previous studies that fiscal policy and monetary policy provide significant multiplier effect to stimulate aggregate demand through increased consumption, investment, government consumption, exports and imports [6]. Expansionary fiscal and monetary policies increase production by encouraging the business sector to increase investment. On the other hand, aggregate demand is strong enough to encourage businesses to increase production in order to meet the demand.

\section{REFERENCES}

[1] Solikin, "Analisis kebijakan moneter dalam model makroekonometrik struktural jangka panjang," Buletin Ekonomi Moneter dan Perbankan, pp. 191-229, September 2005.

[2] S. Iskandar, "Koordinasi kebijakan moneter dan fiskal di Indonesia: Suatu kajian dengan pendekatan game theory," Buletin Ekonomi Moneter dan Perbankan, pp. 5-30, January 2007.

[3] S. Iskandar and J. Adamanti, "Peran stimulus fiskal dan pelonggaran moneter pada perekonomian indonesia selama krisis finansial global: Dengan pendekatan financial computable general equilibrium," Buletin Ekonomi Moneter dan Perbankan, pp. 170-192, October 2010.

[4] M. Yunanto, "Dampak kebijakan fiskal moneter terhadap produk domestik bruto (PDB) Indonesia Tahun 1990-2011," Ph.D. dissertation, Faculty of Economics, Gunadarma University, 2013.

[5] M. Yunanto and H. Medyawati, "Macroeconomic structural change in Indonesia: In the period of 1990-2011," International Journal of Trade, Economics and Finance, vol. 4, no. 3, June 2013.

[6] M. Yunanto and H. Medyawati, "Monetary and fiscal policy in internal and external balance," in Proc. International Congress on Interdisciplinary Behavior and Social Sciences, Bali, Indonesia, 2014.

[7] Y. Muhammad and H. Medyawati, "Monetary and fiscal policy analysis: Where more effective (unpublished)?" Journal of Indonesian Economy and Business, Universitas Gajah Mada, Faculty of Economy and Business, 2015.

[8] M. N. Gregory, Macroeconomics, $6^{\text {th }}$ ed. Worth Publishers, New York and Basingstoke US, 2007.

[9] B. Carlos, "International transmission of monetary shocks with interest rate rules," Universidad de Valladolid, Departamento de Fundamentos del Análisis Económico, DT 00-04, 2000.

[10] A. A. M. M. dan A. Tohari, “ Peranan kebijakan moneter dalam menjaga stabilitas perekonomian indonesia sebagai respon terhadap fluktuasi perekonomian dunia," Buletin Ekonomi Moneter dan Perbankan, pp. 145-177, October 2006.

[11] W. Perry, "Stabilitas sistem perbankan dan kebijakan moneter: Keterkaitan dan Perkembangan di Indonesia," Bulletin Ekonomi Moneter dan Perbankan, pp. 429-454, Maret 2006.

[12] B. Ben, J. Boivin, and P. Eliasz, "Measuring the effects of monetary policy: A factor-augumented vector autoregressive approach," Quarterly Journal of Economics, vol. 120, issue 1, pp. 387-422, 2005.

[13] M. Frederick, "The role of output stabilization in the conduct of monetary policy," Working Paper No. 9291, NBER, 2002.

[14] C. Lawrence, M. Eichenbaum, and C. Evans, "Monetary policy shocks: what have me learned and to what end?" in The Handbook of Macroeconomics, W. Michael and J. Taylor, Eds. North-Holland, Amsterdam, 1999, pp. 65-148.

[15] M. S. Rafiq and S. K. Mallick, "The effect of monetary policy on output in EMU3: A sign restriction approach," Journal of Macroeconomics, vol. 30, issue 4, pp. 1756-1791, 2008.

[16] W.-J. Hsieh, "Study of the behavior of the Indonesian Rupiah/US dollar exchange rate and policy implications," International Journal of Applied Economics, vol. 6, issue 2, pp. 41-50, 2009. 
[17] W. Ekonometrika, Teori Dan Aplikasi Untuk Ekonomi Dan Bisnis, Ekonisia FE UII, Yogyakarta, 2007.

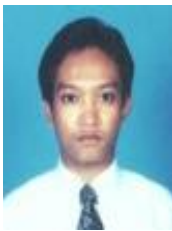

Muhammad Yunanto is a lecturer in Gunadarma University. He was born in Klaten on June 12, 1969. He got an undergraduate program in economics, a master program in management, and completed the doctoral program majoring in economics from Gunadarma University, Indonesia, in 2013. He was a lecturer teaching subject in macro economics, strategic management, and 1993.

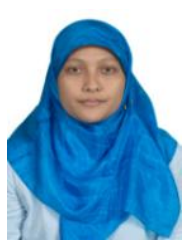

Henny Medyawati is a lecturer in Gunadarma University. She was born in Jakarta on May 18, 1970. She got the undergraduate program in computer science, a master program in management, and completed the doctoral program in economics at Gunadarma University, Depok, Indonesia on March 5, 2010. She is a lecturer teaching subject in banking information system, electronic banking, and management in Gunadarma University since 1993.

She experience as an instructure in banking system application course, and attended in SAP course in fundamental and financial module at Gunadarma University. As a lecturer, she also served in the head development laboratory at LEPMA in Gunadarma University. 